trap after all visible bait had been removed. The metal treadle of the Victor snap trap would not be as effective in this situation.

Although the Museum Special was more effective than the Victor snap trap for capturing small mammals, each of the two types of traps could be used at a trap station. The Victor trap is useful during rainy periods when most of the Museum Special traps are tripped. More than one of each trap type might be used in areas of high density. In this study, the number of multiple captures at one station was only 10 out of a total of 497 small mammals captured.

The two types of snap-traps used in this study were only effective for capturing animals which weighed less than fifty grams. Neither type of trap was effective for capturing animals as large as the cotton rat Sigmodon hispidus S a \& O rd, $1825(84 \mathrm{~g})$. Wood rats Neotoma floridana (O rd, 1318) (237 g) were occasionally stunned by the traps, but rarely killed.

\title{
REFERENCES
}

C ock r u m E. L., 1947: Effectiveness of live traps versus snap traps. J. Mammal, 28: 186. Gentry J. B., Golle y F. B. \& S m ith M. H., 1968: An evaluation of the proposed International Biological Program census method for estimating small mammal populations. Acta theriol., 13: 313-327. Golle y F. B., 1962: Mammals of Georgia. Univ, of Gorgia Press, Athens. Goodnight C. J. \& Koestner E. J., 1942: Comparison of trapping methods in an Illinois prairie. J. Mammal, 23: 435-438. Grodziński W., Pucek Z. \& Ryszkowski L., 1966: Estimation of rodent numbers by means of prebaiting and intensive removal. Acta theriol., 11: $297-314$. K a u f man D. W., S mith G. C., J ones R. M., Gentry J. B. \& S mith M. H., 1971: Use of assessment lines to estimate density of small mammals. Acta theriol., 16: 127-147. Ne a l B. R. \& Cock A. G., 1969: Analysis of the selection of small Afican mammals by two break-back traps. J. Zool. (Lond), 158: 335-340. S e a lander J. A. \& J a m e s D., 1958: Relative efficiency of different small mammal traps. J. Mammal., 39: 215-223.

Savannah River Ecology Laboratory, Drawer E, Aiken, South Carolina 29801, or Department of Zoology and Institute of Ecology, University of Georgia, Athens, Georgia, USA 30601. Accepted, March 15, 1971.

Marek GĘBCZYŃSKI

\section{OXYGEN CONSUMPTION IN STARVING SHREWS}

ZUZYCIE TLENU U GEODUJACYCH RYJOWEK

The experiments were carried out on fed and starving shrews Sorex minutus, S. araneus and Neomys fodiens. The hypothesis suggesting the ability of shrews to fall into the state of reversible hypothermy under the effect of lack of food was not confirmed.

B a shenina (1965) suggested that shrews devoid of food in cold surroundings are not able to maintain normal body temperature. This supposition was based on the measurement of oxygen consumption in 
one individual of Lesser shrew, Sorex minutus Linnaeus, 1776, which amounted to $1.4441 \mathrm{cc} / \mathrm{g} \min$ at $5^{\circ} \mathrm{C}$. After $3.5 \mathrm{~h}$ fasting at this temperature the oxygen consumption decreased several fold and was equal to $0.4240 \mathrm{cc} / \mathrm{g} \mathrm{min}$. Therefore the conclusion was drawn that with the lack of food shrews cannot maintain sufficiently high metabolism rate required for constant body temperature.

Since this hypothesis contradicted current ideas on the physiology of thermoregulation in shrews an attempt has been made to verify it. The experiments were carried out not only with $S$. minutus, but also with Common shrew, Sorex araneus Linnae us, 1758, and Water shrew, Neomys fodiens (P e n n a n t, 1771).

\section{MATERIAL AND METHOD}

Altogether 38 Lesser shrews, 36 Common shrews and 2 Water shrews were investigated. The animals were captured in damp biotopes of the Białowieża National Park, in the years 1966-1970. The measurements were in principle carried out on the day of capture, except some individuals kept for a few days in the laboratory.

The animals were regarded as fed when they had a free access to food before the commencement of the experiment. Starving shrews were kept in cages without food for variable periods: $2-2.5 \mathrm{~h}$ in the case of $S$. minutus, and 2 to 4 hours in $S$. araneus and $N$. fodiens. The experiments with starving animals were carried out only once while those with fed animals were sometimes repeated.

Oxygen consumption was determined in respirometers of the closed type. In experiments lasting 30 to $60 \mathrm{~min}$ a Kalabukhov-Skvortzov apparatus was used, and with longer measurements Morrison's respirometer was employed.

\section{RESULTS AND DISCUSSION}

The results of short-term experiments carried out on starving or fed shrews are not quite unequivocal. Although in great majority of cases fasting shrews showed decreased oxygen consumption. Only in two Lesser shrews in winter, and in three overwintered animals, the fasting at the temperature around $5^{\circ} \mathrm{C}$ resulted in the increase of oxygen consumption in comparison with fed individuals (Table 1).

The reduction of metabolism in starving shrews did not exceed 17 per cent, and only in one case the difference was higher and amounted to 35.9 per cent (Table 1). This differentiation of the metabolism level in starving shrews may be explained by various behaviour. In some animals a similar mobility to that in fed shrews is observed, and their slightly lower metabolism rate is probably due to the lack of specific dynamic action of food. The remaining starving individuals showed either reduced or greatly increased activity. Of course this must be accompanied by corresponding reduction or increase in oxygen consumption. This marked differentiation of activity of fasted individuals is supported by the value of standard deviation computed for a few more numerous series of 
determinations. In all cases S.D. is higher in starving than in fed individuals (Table 1).

The obtained data are only partially comparable with the results of $\mathrm{B}$ a s he nin a (1965). The value of oxygen consumption in S. minutus starving for 3.5 hours $(25.44 \mathrm{cc} / \mathrm{g} \mathrm{hr}$ - computed by the author) reported by Bashenina does not differ significantly from the data given above. On the other hand the value of $86.64 \mathrm{cc} / \mathrm{g} \mathrm{hr}$ (computed by the author) found by $\mathrm{B}$ ashenina in a fed individual was never observed in the present experiments. The highest value registered in the present series of measurements only slightly exceeded $30.0 \mathrm{cc} / \mathrm{g} \mathrm{hr}$ (Table 1).

Table 1

Oxygen consumption by fed or starving shrews.

$\mathrm{n}$ - Number of measurements. The period of measurements varied from 30 to 60 min. A - Ratio of oxygen consumption in fed and in starving shrews, in per cents.

\begin{tabular}{|c|c|c|c|c|c|c|c|c|}
\hline \multirow[b]{2}{*}{ Season \& age } & \multirow{2}{*}{$\underset{{ }^{\circ} \mathrm{C}}{\text { Temp., }}$} & \multicolumn{3}{|c|}{ Fed } & \multicolumn{3}{|c|}{ Starving } & \multirow{2}{*}{ A } \\
\hline & & $\begin{array}{l}\text { Body } \\
\text { wt., g }\end{array}$ & $\begin{array}{l}\mathrm{cc} / \mathrm{g} \mathrm{hr} \\
\pm \text { S.D. }\end{array}$ & $\mathrm{n}$ & $\begin{array}{l}\text { Body } \\
\text { wt., g }\end{array}$ & $\begin{array}{l}\mathrm{cc} / \mathrm{g} \mathrm{hr} \\
\pm \text { S.D. }\end{array}$ & n & \\
\hline \multicolumn{9}{|c|}{ Sorex minutus } \\
\hline $\begin{array}{l}\text { Spring, old } \\
\text { Spring, old } \\
\text { Summer, young } \\
\text { Summer, young } \\
\text { Summer, old } \\
\text { Summer, old } \\
\text { Autumn, young } \\
\text { Winter, young }\end{array}$ & $\begin{array}{r}4.5 \\
15 \\
5 \\
17 \\
16 \\
25 \\
10 \\
5\end{array}$ & $\begin{array}{l}4.24 \\
4.37 \\
3.05 \\
3.20 \\
4.95 \\
4.40 \\
2.80 \\
2.65\end{array}$ & $\begin{array}{l}22.86 \pm 2.01 \\
12.57 \pm 0.78 \\
31.64 \\
13.84 \\
12.67 \\
12.28 \\
21.60 \\
24.02 \pm 0.36\end{array}$ & $\begin{array}{r}16 \\
22 \\
2 \\
1 \\
2 \\
1 \\
1 \\
5\end{array}$ & $\begin{array}{l}4.07 \\
4.48 \\
2.80 \\
3.10 \\
485 \\
4.45 \\
2.45 \\
2.55\end{array}$ & $\begin{array}{l}25.95 \\
12.37 \pm 3.42 \\
25.56 \pm 2.31 \\
11.53 \\
11.31 \\
7.87 \\
18.56 \\
24.66\end{array}$ & $\begin{array}{r}3 \\
16 \\
8 \\
1 \\
2 \\
1 \\
3 \\
2\end{array}$ & $\begin{array}{r}113.5 \\
98.4 \\
83.9 \\
83.3 \\
89.3 \\
64.1 \\
85.9 \\
102.7\end{array}$ \\
\hline \multicolumn{9}{|c|}{ Sorex araneus } \\
\hline $\begin{array}{l}\text { Summer, young } \\
\text { Summer, young } \\
\text { Summer, young }\end{array}$ & $\begin{array}{r}20 \\
15 \\
3\end{array}$ & $\begin{array}{l}7.52 \\
7.34 \\
6.00\end{array}$ & $\begin{array}{r}9.63 \pm 0.96 \\
13.34 \pm 1.25 \\
18.60\end{array}$ & $\begin{array}{r}12 \\
6 \\
3\end{array}$ & $\begin{array}{l}6.72 \\
7.80 \\
6.20\end{array}$ & $\begin{array}{r}9.56 \pm 1.47 \\
12.21 \pm 2.67 \\
16.20\end{array}$ & $\begin{array}{r}12 \\
19 \\
3\end{array}$ & $\begin{array}{l}99.3 \\
91.5 \\
87.1\end{array}$ \\
\hline \multicolumn{9}{|c|}{ Neomys fodiens } \\
\hline Autumn, young & 20 & 17.10 & 5.66 & 2 & 15.80 & 5.45 & 2 & 91.0 \\
\hline
\end{tabular}

In order to estimate the rate of oxygen consumption in shrews devoid of food several continuous and long-term experiments were carried out. One $S$. minutus captured in winter was placed in the experimental chamber immediately after being brougth from its habitat. For the first two hours it was left without food, and in this time oxygen consumption slightly decreased (Fig. 1A). Then a portion of meat $(2 \mathrm{~g})$ was provided. The animal consumed it during approximately $30 \mathrm{~min}$ and for the next 5 hours the metabolism remained constant (Fig. 1A). In the last hour oxygen consumption decreased by approximately 30 per cent, the activity of the animal was gradually reduced and the shrew died. 


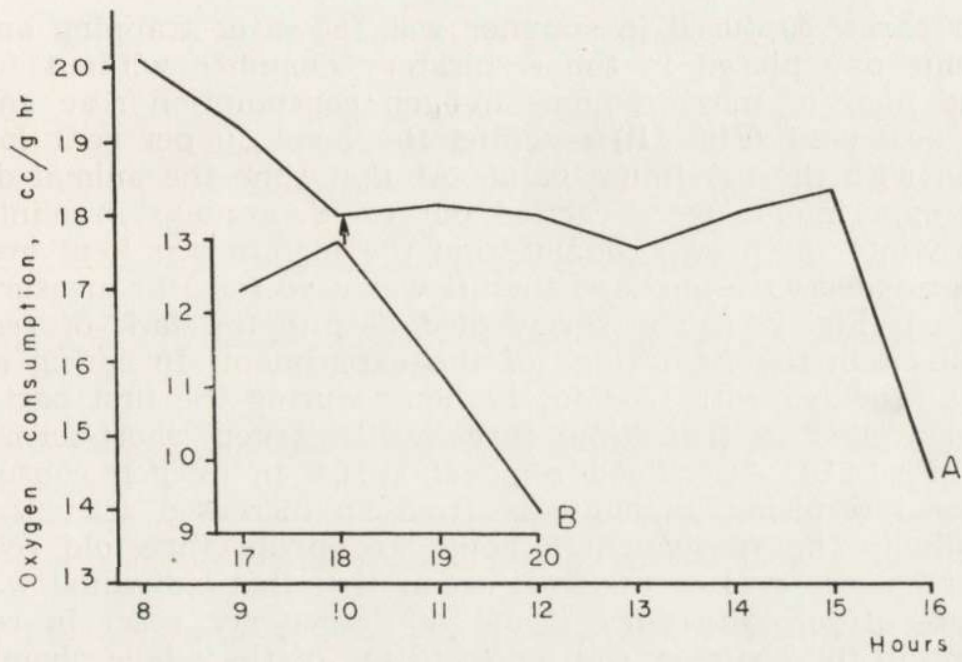

Fig. 1. Oxygen consumption in starving Lesser shrews.

A - February, young male, temperature $10^{\circ} \mathrm{C}$, body weight was equal to $2.80 \mathrm{~g}$ before the experiment and $2.55 \mathrm{~g}$ after the experiment. The arrow indicates the moment of giving $2 \mathrm{~g}$ of meat which was consumed during next $30 \mathrm{~min}$. B - June, young male, temperature $16^{\circ} \mathrm{C}$, body weight was equal to $2.80 \mathrm{~g}$ before the experiment and $2.55 \mathrm{~g}$ after the experiment.

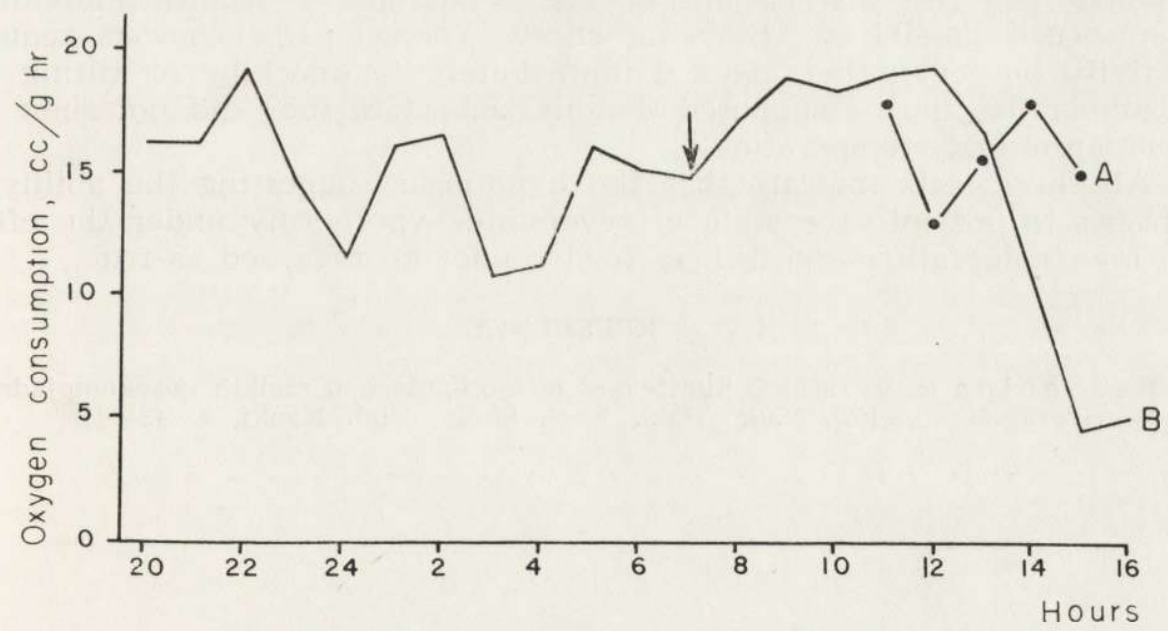

Fig. 2. Oxygen consumption in Common shrew in the presence of food and without food.

A - February, young female, temperature $5^{\circ} \mathrm{C}$, body weight was equal to $6.30 \mathrm{~g}$ before the experiment and $5.60 \mathrm{~g}$ after the experiment. B - May, overwintered male, temperature $5^{\circ} \mathrm{C}$, body weight was equal to $8.70 \mathrm{~g}$ before the experiment and $6.90 \mathrm{~g}$ after the experiment. The arrow indicates the beginning of the period when the shrew was deprived of food. 
A lesser shrew captured in summer was fed after trapping and then on the same day placed in the respiratory chamber without food. In the second hour of measurements oxygen consumption rose and then gradually decreased (Fig. 1B) reaching the level 30 per cent lower in comparison with the maximum value. At that time the animal died.

Similar experiments were carried out on $S$. araneus in winter and spring. In winter a shrew brought from the terrain was kept overnight in a cage provided with food and then it was used for $5 \mathrm{hr}$ measurements without food (Fig. 2A). The shrew died despite the lack of reduction of metabolism in the final stage of the experiment. In spring another shrew was provided with food for 12 hours during the first part of the measurement, and in that time three well-marked short-term cycles appeared (Fig. 2B). After food removal a rise in oxygen consumption was observed resulting undoubtedly from an increased activity of the shrew. Only in the subsequent 6 hours an abrupt threefold reduction of the metabolism level occurred. It seems that this individual was then in the state of torpidity since it did not move nor react in response to knocking in the chamber wall or to tilting of the whole chamber.

This last experiment is the only proof that during long starving the shrew may significantly reduce the metabolism rate. It appears, however, that the animal cannot rise again body temperature and must die. Thus the process is probably irreversible and it may be supposed that it occurs also in nature leading to the death of shrews. The hypothesis on the possibility that in unfavourable conditions shrews may fall in the state of torpidity was not confirmed by any of the experiments. Also the observations on the behaviour of studied individuals deny such possibility. Starving shrews occasionally showed reduced activity but even then reacted immediately to knocking or tilting the chamber. It may be supposed that in such state they did not show reduction of body temperature.

All these facts indicate that the hypothesis suggesting the ability of shrews to fall into the state of reversible hypothermy under the effect of low temperature and lack of food cannot be regarded as true.

\section{REFERENCE}

B a s h e n in a N. V. 1965: O himičeskoj termoregulacii u melkih nasekomojadnych (Insectivora, Mammalia). Nauč. Dokl. Vysš. Školy, Biol. Nauki, 4: 43-47. 